Final report of research performed from 1 March 1997 - 28 February 2006 under Interagency

Agreement, DE-AI02-97ER62341, entitled

\title{
DEVELOPMENT OF IMPROVED TECHNIQUES FOR SATELLITE REMOTE SENSING OF CLOUDS AND RADIATION USING ARM DATA
}

\author{
Principal Investigator \\ Dr. Patrick Minnis \\ NASA Langley Research Center, Hampton, VA \\ p.minnis@nasa.gov \\ Co-Investigators \\ Louis Nguyen, William L. Smith Jr. \\ NASA Langley Research Center, Hampton, VA \\ David P. Duda \\ Science Systems and Applications, Inc., Hampton, VA \\ Xiquan Dong \\ University of North Dakota, Grand Forks, ND
}

28 June 2013

\begin{abstract}
During the period, March 1997 - February 2006, the Principal Investigator and his research team co-authored 47 peer-reviewed papers and presented, at least, 138 papers at conferences, meetings, and workshops that were supported either in whole or in part by this agreement. We developed a state-of-the-art satellite cloud processing system that generates cloud properties over the Atmospheric Radiation (ARM) surface sites and surrounding domains in near-real time and outputs the results on the world wide web in image and digital formats. When the products are quality controlled, they are sent to the ARM archive for further dissemination. These products and raw satellite images can be accessed at http://cloudsgate2.larc.nasa.gov/cgibin/site/showdoc?docid=4\&cmd=field-experiment-homepage\&exp=ARM and are used by many in the ARM science community. The algorithms used in this system to generate cloud properties were validated and improved by the research conducted under this agreement. The team supported, at least, 11 ARM-related or supported field experiments by providing near-real time satellite imagery, cloud products, model results, and interactive analyses for mission planning, execution, and post-experiment scientific analyses. Comparisons of cloud properties derived from satellite, aircraft, and surface measurements were used to evaluate uncertainties in the cloud properties. Multiple-angle satellite retrievals were used to determine the influence of cloud structural and microphysical properties on the exiting radiation field.
\end{abstract}

\section{Introduction}

Clouds are the dominant modulators of radiation in the atmosphere. Accurate observations of 
cloud properties and their relationship to the radiation fields are needed to improve and constrain radiative transfer models (RTM), cloud process models and general circulation models (GCMs). In this role, such observations are critical to the goals of the ARM program. Satellite data can provide quantification of the radiation fields exiting the top of the atmosphere (TOA) and, through remote sensing analysis, can yield many of the bulk cloud properties essential for quantifying atmospheric liquid and ice water and their radiative properties over a variety of scales in a given domain. Additionally, remote sensing can be used to estimate surface radiative properties like albedo and emissivity that are essential for understanding the radiative interaction between the surface and atmosphere. Even more importantly, accurate characterization of the surface radiative properties is essential for deriving cloud properties from satellite data. Cloud properties such as optical depth, particle size, phase, ice and liquid water paths, and cloud height and thickness are necessary to link the atmospheric hydrological cycle to the radiation budget. Thus, increases in accuracy of satellite-derived cloud products and radiative fluxes derived from observations provide the basis for improvements in formulations of the processes that produce clouds in models and interact with the radiation budget. The goals of our proposal are summarized under six broad objectives that apply to ARM surface sites and field programs:

\section{Calibrate sensors used to retrieve satellite cloud and radiation properties for ARM}

2. Develop techniques for improved characterization of clear-sky radiances for remote sensing and radiative flux determination.

3. Test and develop methods to derive cloud properties including cloud ice water path from satellite-observed radiances in all conditions, including multilayered clouds.

4. Validate and improve the measurements of broadband radiation at the top of the atmosphere over the ARM sites.

5. Provide satellite support for ARM field programs.

6. Investigate cloud phenomena related to the ARM surface sites.

During the period of study, we made considerable broad progress in addressing the problems in remote sensing of clouds and determination of the radiation budget at the top of the atmosphere and at the surface using narrowband data. Some of the work conducted under this agreement was completed and/or published after the end of the study period. Our accomplishments in addressing those goals are summarized below. The full details are documented in our publications. We co-authored 47 published peer-reviewed manuscripts ( $A 1$ A47). A total of 138 papers were presented at scientific meetings with at least 85 published in proceedings.

\section{Data}

Our primary satellite datasets for deriving cloud and radiation parameters consist of radiances from the Geostationary Operational Environmental Satellite (GOES) imager (0.65, 3.9, 6.7, 10.8, and $12.0 \mu \mathrm{m}$ ) for the ARM Southern Great Plains (SGP) area, the Japanese Geostationary Meteorological Satellite (GMS) imager $(0.65,10.8$, and $12.0 \mu \mathrm{m})$, GOES-9, and MTSAT-1R for the ARM Tropical Western Pacific (TWP) domain, Meteosat-8 SEVIRI for the European and African experiment areas, and the Sun-synchronous NOAA series $(11,12,14,15,16)$ Advanced Very High Resolution Radiometer (AVHRR) 1-km imager (0.65, 0.86, 3.7, 10.8, and $12.0 \mu \mathrm{m}$; and $1.6 \mu \mathrm{m}$ on NOAA-15) over the ARM North Slope of Alaska (NSA) and all other areas. Secondary and supporting datasets include the Tropical Rainfall Monitoring Mission (TRMM) satellite with the Visible InfRared Scanner (VIRS; 0.65, 1.6, 3.7, 10.8, and $12.0 \mu \mathrm{m}$ ) radiances 
and fluxes from the Clouds and Earth's Radiant Energy System (CERES) broadband scanners (shortwave, SW: 0.2 - $5.0 \mu \mathrm{m}$; longwave, LW: 5 - $50 \mu \mathrm{m}$ ) and the Earth Radiation Budget Experiment (ERBE) scanners and wide field of view (WFOV) instruments on ERBS, NOAA-9, and NOAA-10. The TRMM instruments began observing December 28, 1997 between $38^{\circ} \mathrm{S}$ and $38^{\circ} \mathrm{N}$ and acquired 9 months of CERES data. The VIRS is still operating. CERES data and multispectral imagery from the Moderate Resolution Imaging Spectroradiometer (MODIS) are taken by the Terra and Aqua satellites that have 1030 and 1330 LT equatorial crossing time, respectively. Multispectral data from the second Earth Resources Satellite Along-Track Scanning Radiometer (ATSR-2) were also used in some of the analyses.

\section{Research Tasks}

\subsection{Calibration}

Before testing and validating satellite retrievals using ARM and other datasets, it is essential that the satellite data are properly calibrated. Operational satellite imagers, especially their visible channels are generally poorly calibrated. To obtain the best calibrations possible, we calibrated the GOES-8 channels against a variety of research satellite imagers including the VIRS, ATSR-2, and MODIS, which carry onboard calibration systems that are often superior to those on operational meteorological satellites. Our initial study (A16) revealed a consistent trend in the GOES-8 VIS calibration. However, the resulting absolute calibration of the GOES imager was different for each satellite. Some of the differences could be attributed to differences in the filter functions for each instrument, but outstanding discrepancies indicate that the three research satellite imagers differed in their absolute calibration. The VIRS calibration was selected as the reference for calibrating the VIS channel on the operational satellites used in our ARM studies prior to 2007. It was selected because the optical depths derived using the ATSR-2 calibration were too low compared to surface retrievals and the MODIS data were still preliminary. The reference calibration may change again if warranted by additional evidence.

The infrared channels were also compared, but the differences between one satellite and another were no greater than the accuracy of the given satellite instrument and the differences expected from the filter functions for each channel (A17). A method to rapidly calibrate the various geostationary and Sun-synchronous satellites was also developed by demonstrating that the calibration of GOES to VIRS can be easily and accurately transferred from the GOES-8 to another geostationary satellite using data taken every day (C96), thus ensuring that the calibrations between the satellites are consistent and can be used to monitor any sudden shifts in the calibration of one or the other satellite $(C 22, C 23, C 38, C 43, C 45, C 56, C 57, C 89, C 98)$. We also developed an independent method to detect trends in the visible channel calibrations using the reflectivity of deep convective clouds (C95). These satellite calibrations, which have been supported both by ARM and CERES, represent a significant contribution of ARM to the remote sensing and radiation community. They also have an important positive impact on the derived cloud products and shortwave albedos derived from the VIS data.

\subsection{Surface and clear-sky radiance characterization}

Bidirectional reflectance distribution functions BRDFs are necessary to describe the anisotropic reflectance patterns from natural surfaces and the atmosphere. They are also critical in the prediction of clear-sky reflectance for cloud detection and for computing the albedo from a reflectance measurements. BRDFs were developed for clear land using radiance measurements from the ARM Unmanned Aerospace Vehicle (UAV) Multispectral Pushbroom Imaging 
Radiometer (MPIR; see A8) and CERES-ARM Radiation Experiment (CARE) helicopter data (C2) taken over the areas surrounding the ARM SGP central facilities. These models along with the GOES and ERBE BRDFs that are currently used in operational ARM and CERES cloud retrievals, and radiative flux inversions were tested using matched intercalibrated GOES-8, GOES-10, TRMM VIRS, NOAA-12 and 14 AVHRR visible channel datasets over the ARM SGP domain (C11). The comparisons of the narrowband visible albedos derived from dual, collocated satellite measurements indicated that the ERBE and GOES models, in general, produced the smallest bias and random errors, while the CARE and MPIR models produced the most significant errors in albedo. Although the latter pair were derived directly from central Oklahoma data, they were not as representative as the other models because the atmospheric corrections and angular sampling were insufficient. The comparisons and helicopter measurements indicated that some asymmetric diurnal variations of spectral reflectance occurred for some areas, however the results are not conclusive. All of the models, except CARE, produced acceptable errors in albedos for low solar zenith angles (NOAA-14 AVHRR). The RMS errors ranged from 22 to $35 \%$ for high solar zenith angles (NOAA-12). Differences in the filter functions of sensors indicate that UAV imagers can be used to develop useful BRDFs at the TOA if the UAV flies high enough and obtains more complete angular coverage than was possible during the ARM UAV field experiments.

BRDFs were developed for clear snow using theoretical calculations assuming that the snow is similar to an optically thick ice cloud. To simulate the reflectance of clear snow, addingdoubling calculations were performed using a randomly oriented hexagonal ice crystal with an effective diameter of $135 \mu \mathrm{m}$ in a cloud with an optical depth of 1000 . The resulting bidirectional reflectance values were compared to AVHRR and MODIS observations taken over the Arctic Ocean, Greenland, and Antarctica. The theoretical model agreed quite well with the AVHRR observations over the Arctic except for the forward scattering direction where the observations tended to be somewhat greater than the theoretical values at higher viewing zenith angles $(C 30)$. Initial examination of the data indicates the presence of low-level haze that causes the forward scattering discrepancies. The model calculations for 3.7 and 1.6- $\mu \mathrm{m}$ channels revealed the same trends in clear-snow reflectance as seen from MODIS data taken over both poles. However, the observations show an overall greater reflectance than computed with the model. Some of the differences may be related to the optical depths used and to the MODIS calibrations (C29). The theoretical models were adjusted to the observations and have been used to improve the detection of clouds over snow surfaces (C36).

As a first step towards improving estimates of surface temperature in cloudy conditions, we examined the relationship between skin temperature and cloud shadowing at the ARM SGP central facility under overcast and partly cloudy skies (C6). Surface skin temperature was measured by the down-looking wide field-of-view infrared $(9.6-11.5 \mu \mathrm{m})$ pyrometer, while the up-looking SIRS or BSRN pyranometers measured the total downward shortwave $(0.2-5 \mu \mathrm{m})$ hemispheric irradiance. Skin temperatures derived from 1-min averages of the IR data were compared to the air temperatures measured at a height of $2 \mathrm{~m}$. Under overcast conditions at night, the $2 \mathrm{~m}$ air and skin temperatures were within $1 \mathrm{~K}$ of each other. In daytime under both overcast and mostly cloudy conditions, the air/skin temperature differences correlated well with the downward shortwave hemispheric irradiance suggesting that skin temperature can be accurately estimated from surface air temperature during cloudy conditions. Partly cloudy conditions are more complex. A comparison of the skin temperature and shortwave irradiance under skies with scattered cumulus showed that the skin temperature at SGP reacts rapidly to changes in solar 
insolation. The lag between the shortwave irradiance and skin/air temperature differences is less than $1 \mathrm{~min}$. Under such conditions, skin temperature can fluctuate as much as $10 \mathrm{~K}$ in $3 \mathrm{~min}$. In nighttime ARESE GOES imagery, the skin temperatures in clear regions were substantially less than those underneath adjacent areas with low cloud cover. The local air temperature provided a good estimate of the cloudy-sky surface skin temperature resulting in a much better analysis of cloud properties at night.

Our follow-on study (C53) using 1998 surface-based skin and air temperatures at the SGP central facility $(\mathrm{SCF})$ and skin temperatures derived from clear-sky GOES-8 data over a $0.5^{\circ}$ region centered on the SCF generally confirmed the initial results. The maximum skin temperature exceeds the maximum air temperature in clear skies but both temperatures converge near sunrise. The skin temperatures derived from GOES-8 differed substantially from those derived from the surface suggesting that the ARM SCF measurements are not particularly representative of the larger area in general. The greatest differences occurred at night for partly and mostly cloudy conditions when GOES only observed the cold clear areas while the surface radiometer measured both cloud-blanketed and cloud-free scenes. Some of the differences seen in the daytime data can be attributed to anisotropic warming of the surface components. Using dual satellite measurements and matched aircraft and satellite data as well as helicopter measurements, we demonstrated definitively that during the daytime the facets of any land surface warm according to their exposure to the sun and vegetation type resulting in anisotropic emission $(A 6, C 1)$. The derived skin temperature depends on the viewing and illumination angles as well as the surface morphology (terrain and vegetation). Thus, a skin temperature derived from a fixed satellite position will vary considerably relative to that from a hemispheric radiometer at a fixed location. The result is a diurnal cycle in the difference between the two measurements. Similar effects also occur in partly cloudy conditions when cloud shadows cool the surface. A satellite may view various amounts of shadowing depending on the particular time of day. The result may be a diurnally dependent bias in the skin temperature derived from the satellite data and subsequently on any dual angle retrievals that assume a uniform emission that is independent of viewing angles. Methods are needed to correct for anisotropy in the satellite skin-temperature retrievals and for broken cloud conditions. An initial set of methods was determined using CERES data and tested using ARM skin temperature datasets (C103).

Surface microwave emissivities in the SGP area were found to vary substantially with soil moisture and time of day, perhaps due to the effects of dew $(A 7, C 8)$. An improved technique for deriving surface emissivity was developed to include, more explicitly, the contributions of downwelling atmospheric radiation to the surface radiation balance need to compute the emissivity (C46). The method has been applied to both GOES and MODIS data $(C 78, C 99)$.

\subsection{Improvement and validation of cloud property retrievals}

\section{Algorithm Improvement}

Improvement of the various algorithms has progressed considerably. The primary algorithms used for deriving cloud properties include the Layer Bispectral Threshold Method (LBTM), the Visible Infrared Solar-infrared Split-window Technique (VISST), and the Solar-infrared Infrared Split Window Technique (SIST). The last two methods are multispectral and are applied to satellites with the proper spectral complements. The LBTM uses only VIS and IR data and can be applied to most operational satellite imagers. It also serves as the primer algorithm for the multispectral techniques. The SIST is primarily used at night, while VISST is used during the day because it utilizes the VIS data to obtain more reliable estimates of thick-cloud optical depth. 
All of these algorithms have been improved and are being used regularly. New infrared emittance models were developed and implemented to improve the interpretation of low clouds that are warmer than or near the same temperature of the surface $(A 2, C 9)$. These new models are especially important for deriving low-cloud properties at night $(C 24, C 25)$. A new visible reflectance parameterization was developed (C58) that greatly improves the accuracy of the retrievals from clouds over any surface type relative to the older parameterization that was used. The parameterization yields reflectances that are unbiased for all surface albedos and that reproduce adding-doubling results for clouds over surfaces with albedos from 4-10\%, 10-50\%, and $50-90 \%$ to within $0.5 \%, 0.7 \%$, and $1.0 \%$, respectively for all levels of cloud optical depths, phase, and particle size. The new parameterization can also reproduce the non-monotonic reflectance variation of clouds over bright surfaces, a capability absent from the earlier technique.

The new models and parameterizations were incorporated into SIST and VISST, which were then used together in an operational code to process GOES and other geostationary satellite data in a near-real time fashion $(C 20, C 24, C 31, C 44)$. This near-real time algorithm ingests hourly $40-\mathrm{km}$ resolution forecast analyses form the Rapid Update Cycle (RUC) numerical weather prediction model, then computes expected clear-sky reflectances and temperatures in all relevant channels using our derived surface emissivity maps and clear-sky albedo maps with the proper BRDFs and atmospheric corrections based on updated correlated $k$-distribution models (A16, A17) for each channel. A sophisticated multispectral cloud detection algorithm is employed to determine which pixels are cloudy and then applies either VISST or SIST depending on the solar zenith angle (C49). This methodology is currently operating over several ARM domains and producing results that are temporarily archived and displayed within a half hour of receiving the GOES data (see http://cloudsgate2.larc.nasa.gov/cgi-bin/site/showdoc?docid=4\&cmd=fieldexperiment-homepage\&exp=ARM). This methodology has replaced the LBTM for operational processing of ARM GOES data.

Detection of low clouds at night and in low-sun conditions is difficult because of variable surface emissivity and because the signal from the 3.7- $\mu \mathrm{m}$ channel is neutralized in low sun conditions (C49). We have made progress in improving the cloud mask in near terminator conditions using ARM cloud-radar data at the surface $(C 70, C 81, C 116)$. Scattered and broken clouds cause underestimates of cloud optical depth and overestimates of cloud fraction and effective radius. We have demonstrated that combinations of high-resolution visible data can be used with lower resolution infrared data to obtain fractional cloudiness at the pixel level resulting in improved retrievals of cloud properties $(C 49, C 80)$. Detection of clouds over the Arctic was improved using a variety of multispectral techniques and models during both night $(C 19, C 53)$ and sunlit $(A 12, C 10, C 29, C 30)$ conditions. However, retrieval of cloud microphysical properties is extremely difficult during the winter and early spring even with the many channels available on MODIS (C59).

Cloud vertical structure is also important for understanding cloud processes and modeling clouds. Multilayered clouds also affect both satellite detection and retrievals. Using satellite and ARM radar products, we have made progress in identifying those characteristics that can be used to determine which pixels contain overlapped clouds $(C 33, C 60)$. Using matched microwave and visible/infrared sensors, we developed a method for detecting multilayered clouds and deriving the microphysical properties and optical depth of the two ice and liquid water cloud layers comprising the multilayered systems $(A 25, A 36, C 69, C 85, C 104)$. We then improved the model using a new ice-over-water multilayered cloud radiance prediction parameterization (A39), validating each with ARM radar data. We used ARM radar data to estimate the errors in 
retrieved cloud thickness and developed a new algorithm for deriving cloud physical thickness from the retrieved cloud properties $(C 51)$ and validating cloud base heights using ARM and ASOS ceilometer data $(C 107, C 121)$. We used the ARM lidar, radar and ceilometer data along with model and radiosonde humidity profiles to determine the probability of clouds occurring in a given layer $(A 30, C 83, C 102)$ to begin the process of developing a 3-D cloud field. We also explored the combination of satellite, retrievals, ceilometer data, thickness parameterization, surface observations, model data, and ARM site data to develop extensive and local 3- and 4-D cloud fields (C67, C112, C114, C126).

Retrievals of cloud properties are highly dependent on cloud phase and particle size distribution and shape. To help understand these effects, we performed several theoretical and empirical studies. We developed a technique using multiple angle satellite measurements to estimate the ice crystal habit in cirrus clouds $(A 19, A 29)$. With the aid of NSA and MPACE in situ measurements, we developed a method for determining the presence of mixed phase clouds (C119, C132, C133). We used observed in situ cloud data to study the sensitivity of the retrievals to the drop size distribution $(C 120)$ and to the presence of drizzle in low-layer clouds $(C 91)$.

\section{Validation}

Validation studies using ARM surface instrumentation and multi-angle satellite data have helped assess our retrievals using the various algorithms. Over the NSA and Arctic ice pack, radar, lidar, and ceilometer data were used to determine the high accuracy of the cloud fractions and reduced accuracy of the cloud heights derived over the sites (A12,C4,C17,C58). ARM fixed and mobile radar and radiometer data were used to validate the cloud optical depths, effective particle sizes, and LWP/IWP derived from GOES, ATSR-2, MODIS, and AVHRR data (A1, A14, A18, A22, A24, A35, A40, A41, A44, C13, C14, C15, C21, C37, C40, C55, C62, C65, C68, C72, C74, C79, C86, C93, C97, C101, C109, C110, C113, C117, C125, C131, C135). Multi-angle retrievals from two different satellites were used to estimate the instantaneous uncertainties in cloud optical depth and particle size size $(C 31, C 115, C 134)$. Aircraft data were used to validate our retrievals of liquid water properties $(A 14, C 27, C 56, C 108)$ and ice cloud properties $(A 21, A 23, A 28, A 38)$. Analysis of time sequences of GOES imagery with VISST and SIST showing the formation of distrails in supercooled clouds provide additional validation of our phase retrievals $(A 11)$. Ceilometer, lidar, whole sky imager, and radar data were used to validate LBTM cloud amounts and heights over the TWP $(C 7, C 34, C 51)$ and SGP $(C 32, C 52)$.

ARM data have also been critical for improving the surface data that are essential for longterm validation of the satellite retrievals. We used ARM microwave radiometers and aircraft in situ data to develop an improved algorithm for retrieving cloud LWP for both warm and supercooled liquid water clouds $(A 10, C 28, C 46)$ and determined the sensitivity of microwavederived LWP to temperature over polar regions $(A 20, C 75)$. Aircraft in situ data were used to validate the radar retrievals of cloud effective particle size and optical depths used to validate the satellite results $(A 14, A 18, C 3, C 37)$.

Satellite data proved valuable for climate model validation, revealing shortcomings in the models' representation of both low and high cloud cover amounts (A26). Comparisons of model calculations of radiative fluxes using ARM retrievals of atmospheric profiles of temperature and humidity and cloud properties with those retrieved from satellite data revealed shortcomings in both the model and satellite retrieval products $(A 33, C 111)$.

\subsection{Validation and improvement of broadband flux estimates}

One of the most unique features of the satellite retrievals is the TOA broadband flux products 
that cannot be derived accurately from the surface datasets. The GOES-8, GMS, MTSAT, and AVHRR data can be used to provide the TOA broadband fluxes by careful conversion of the narrowband radiances to broadband fluxes. These conversions require the use of BRDFs and limb-darkening models to translate the observed narrowband radiance into a flux or radiance at some reference condition. Empirical narrow-to-broadband model formulae are then used to convert the narrowband fluxes or radiances into broadband fluxes. The conversion formulae have been based on ERBE data matched with GOES, GMS, or AVHRR data taken during the 1980's. Thus, it is essential to validate and improve the determinations of broadband flux and assess subsequent quantities, such as atmospheric absorption, that are derived from it and other data.

We found significant anomalous absorption of shortwave (SW) radiation in clouds using GOES-8 and ARM surface radiometer data taken during 1995 (A5). Subsequent reanalysis of the GOES-8 data using our new VIS calibrations (A16) indicated less absorption than originally estimated (A15). Use of new aircraft and surface radiometers and data reduction techniques as well as new GOES calibrations, models, and CERES data results in better agreement between the model and observed TOA fluxes and atmospheric absorption (A45, C35, C39, C42).

Comparisons of Terra CERES data with the latest GOES- 8 broadband fluxes indicate that the old ERBE conversion functions provide relatively accurate albedos for most seasons, but that the derived longwave (LW) fluxes were biased on average during most months over the Arctic (C53). Some of the bias is due to different viewing conditions, but the greater part is a lack of seasonal variability in the narrow-to-broadband conversions. New and more specific conversion functions based on the latest CERES data could help minimize errors in both SW and LW fluxes (C63, C64). Aircraft and surface radiometer data have also been used to validate the albedos and LW fluxes derived from AVHRR data over the Arctic (A13) resulting in the most accurate cloud radiative forcing data to date over the Arctic $(A 13, C 12, C 16, C 18, C 26)$.

We also explored the use of the ARM satellite retrievals for estimating the surface radiation budget to cover broad areas centered on the ARM sites (C87, C130, C136). Tests using the ARM satellite cloud products showed that the quality of the surface radiative fluxes was equivalent in accuracy to using ISCCP cloud data, but could be produced in near-real time (A43).

\subsection{Participate in and support ARM field programs.}

We participated in a minimum of 12 field programs during the study period. In some instances, we provided on-site interactive support providing real time imagery, cloud products, and model output, while, for others, we provided real time imagery and cloud products on the world wide web only. These field programs are listed in Table 1. Some of these programs are summarized in collaborative journal articles $(A 3, A 8, A 42)$. In addition to onsite support and participation in mission planning, we also conducted collaborative scientific studies using data taken during the field experiments. Our participation resulted in several collaborative efforts to validate cloud properties $(A 18, C 37)$ and better understand the absorption of $\mathrm{SW}$ radiation in the atmosphere $(C 35, C 39, C 42, C 61)$. Our satellite imagery and many of the cloud products are retained online for future analyses at the links shown in Table 1. Various requests to provide specific web products for other experiments arose from the development of ARM IOP web pages.

Analyses from field studies provided large-scale context for the surface and aircraft measurements $(A 12, C 71, C 73)$. They also helped elucidate the impact of aerosols on the microphysical properties of boundary-layer clouds (A31, C92, C118). Combinations of airborne and satellite data were used to determine the properties of deep convective anvils $(A 34, C 82)$. 
Table 1. Field Program participation and support.

\begin{tabular}{|c|c|c|}
\hline Experiment & Period & Web link URL \\
\hline $\begin{array}{c}\text { SHEBA, ARM, \& FIRE Arctic Cloud } \\
\text { Exp }\end{array}$ & $\begin{array}{c}\text { May - August } \\
1998\end{array}$ & cloudsgate2.larc.nasa.gov/arctic/ \\
\hline ARM UAV Phase III & Spring 1999 & $\mathrm{~N} / \mathrm{A}$ \\
\hline ARM UAV Phase IV & Summer 1999 & N/A \\
\hline TWP Nauru '99 & Summer 1999 & cloudsgate2.larc.nasa.gov/arm/TWP/nauru.html \\
\hline Spring Cloud IOP & Spring 2000 & cloudsgate2.larc.nasa.gov/armsgp/ \\
\hline Fall Water Vapor IOP \& AFWEX & Sept - Dec 2000 & N/A \\
\hline ARM UAV & Fall 2002 & cloudsgate2.larc.nasa.gov/armsgp/ \\
\hline MIDCIX & April 2004 & cloudsgate2.larc.nasa.gov/midcix/ \\
\hline MPACE & Fall 2004 & cloudsgate2.larc.nasa.gov/mpace/ \\
\hline MASRAD & Mar-Sept 2005 & $\begin{array}{l}\text { cloudsgate2.larc.nasa.gov/cgi- } \\
\text { bin/site/showdoc?docid=4\&cmd=field- } \\
\text { experiment-homepage\&exp=MASRAD }\end{array}$ \\
\hline TWP-ICE & $\begin{array}{l}\text { Nov } 2005-\text { Feb } \\
2006\end{array}$ & $\begin{array}{l}\text { cloudsgate2.larc.nasa.gov/cgi- } \\
\text { bin/site/showdoc?docid=4\&cmd=field- } \\
\text { experiment-homepage\&exp=TWP-ICE }\end{array}$ \\
\hline RADAGAST & Jan -Dec 2006 & $\begin{array}{l}\text { cloudsgate2.larc.nasa.gov/cgi- } \\
\text { bin/site/showdoc?docid=4\&cmd=field- } \\
\text { experiment-homepage\&exp=niamey }\end{array}$ \\
\hline
\end{tabular}

\subsection{Investigate related cloud phenomena}

In the process of analyzing the satellite and ARM surface datasets, a variety of related scientific studies arise. The development of a validated radar-radiometer retrieval technique led to the determination of a climatology of stratus cloud microphysical properties, cloud fraction and radiative forcing over the SGP Central Facility (A4, A27, A32, C123, C124, C127). These various results should be valuable for modeling studies of boundary layer clouds. Cloud radiative forcing is usually defined in terms of cloud and cloud free cases, but water vapor differs between these cases also, so ARM data were used to determine the contribution of water vapor to the total cloud radiative forcing effect (A37). Efforts to properly navigate the GMS data during Nauru99 led to the discovery of a persistent, diurnally varying cloud plume generated by the island that passes directly over the ARM Nauru site $(A 9, C 5)$. This may cause a bias in the cloud properties and radiation budget at the site relative to the surrounding ocean. Identification of this phenomenon led to a 19-month IOP at Nauru. Satellite and model data over the TWP were used to show the impact of breaking Rossby waves on tropical convection (A46). Improvement of the LWP values derived from the Arctic microwave radiometers (A10) resulted in closer examination of the data and detection of a possible diurnal cycle in cloud LWP over the ice pack (C41) and a different dependence of LWP on cloud temperature relative to that observed in the mid-latitudes $(A 18, C 47)$. The ability to determine phase accurately using the VISST in near-real time has potential for detecting aircraft icing conditions (C27, C55, C76, C77, C94, C105), an unexpected but potentially very useful spin-off from the ARM satellite retrieval studies. The experience and expertise developed by the Principal Investigator in studies using ARM and other datasets led to a request for him to contribute a chapter on remote sensing to a book focused on cirrus clouds (A47). 
The improvement of the algorithms and the need for supporting field programs led the development of near-real time retrieval capabilities that have evolved from the ARM domains (C47, C122) to larger areas that include the ARM domain but provide for wider application of the products $(\mathrm{C} 88, \mathrm{C} 90, \mathrm{C} 100, \mathrm{C} 106, \mathrm{C} 128,129, \mathrm{C} 137, \mathrm{C} 138)$. These results are provided in near-real time for many areas and over other areas with a lag of a few days. Averages of those properties are also provided on various time scales (C66, C84).

\section{Concluding Remarks}

Overall, the research conducted under this interagency agreement was quite fruitful and more than satisfied the objectives of the research. The benefits of the research to the ARM Program and the climate and meteorological community are still being felt in additional advances in the remote sensing of clouds and the use of the results for practical scientific applications.

\section{Publications and Presentations}

All peer-reviewed papers are numbered beginning with "A," while presentations and conferences proceedings are numbered starting with "C."

A1. Mace, G. G., T. P. Ackerman, P. Minnis, and D. F. Young, 1998: Cirrus layer microphysical properties derived from surface-based millimeter radar and infrared interferometer data. J. Geophys. Res., 103, 23,207-23,216.

A2. Minnis, P., D. P. Garber, D. F. Young, R. F. Arduini, and Y. Takano, 1998: Parameterization of reflectance and effective emittance for satellite remote sensing of cloud properties. J. Atmos. Sci., 55, 3313-3339.

A3. Curry, J. A., P. Hobbs, M. D. King, D. A. Randall, P. Minnis, T. Uttal, G. A. Isaac, J. O. Pinto, T. Uttal, A. Bucholtz, D. G. Cripe, H. Gerber, C. W. Fairall, T. J. Garrett, J. Hudson, J. M. Intrieri, C. Jakob, T. Jensen, P. Lawson, D. Marcotte, L. Nguyen, P. Pilewskie, A. Rangno, D. C. Rogers, K. B. Strawbridge, F. P. J. Valero, A. G. Williams, and D. Wylie, 2000: FIRE Arctic Clouds Experiment. Bull. Amer. Meteor. Soc., 81, 5-29.

A4. Dong, X., P. Minnis, T. P. Ackerman, E. E. Clothiaux, G. G. Mace, R. N. Long, and J. C. Liljegren, 2000: A 25-month database of stratus cloud properties generated from groundbased measurements at the ARM SGP site. J. Geophys. Res., 105, 4529-4537.

A5. Valero, F. P. J., P. Minnis, S. K. Pope, A. Bucholtz, B. C. Bush, D. R. Doelling, W. L. Smith, Jr., and X. Dong, 2000: The absorption of solar radiation by the atmosphere as determined using consistent satellite, aircraft, and surface data during the ARM Enhanced Short-Wave Experiment (ARESE). J. Geophys. Res., 105, 4743-4758.

A6. Minnis, P. and M. M. Khaiyer, 2000: Anisotropy of land surface skin temperature derived from satellite data. J. Appl. Meteorol., 39, 1117-1129.

A7. Lin, B. and P. Minnis, 2000: Temporal variations of land surface microwave emissivities over the ARM Southern Great Plains Site. J. Appl. Meteorol., 39, 1103-1116.

A8. Stephens, G. L., R.G. Ellingson, J. Vitko Jr, W. Bolton, T.P. Tooman, F.P.J. Valero, P. Minnis, P. Pilewskie, G.S. Phipps, S. Sekelsky, J.R. Carswell, S.D. Miller, A. Benedetti, R.B. McCoy, R.F. McCoy, Jr, A. Lederbuhr, and R. Bambha, 2000: The Department of Energy's Atmospheric Radiation Measurement (ARM) Unmanned Aerospace Vehicle (UAV) Program, Bull. Am. Meteor. Soc., 81, 2915-2937. 
A9. Nordeen, M. L., P. Minnis, D. R. Doelling, D. Pethick, and L. Nguyen, 2001: Satellite observations of cloud plumes generated by Nauru. Geophys. Res. Lett., 28, 631-634.

A10. Lin, B., P. Minnis, A. Fan, J. A. Curry, and H. Gerber, 2001: Comparison of cloud liquid water paths derived from in situ and microwave radiometer data taken during the SHEBA/FIREACE. Geophys. Res. Lett., 28, 975-978.

A11. Duda, D. P. and P. Minnis, 2002: Observations of aircraft dissipation trails from GOES. Mon. Wea. Rev., 130, 398-406.

A12. Minnis, P., V. Chakrapani, D. R. Doelling, L. Nguyen, R. Palikonda, D. A. Spangenberg, T. Uttal, R. F. Arduini, and M. Shupe, 2001: Cloud coverage during FIRE ACE derived from AVHRR data. J. Geophys. Res., 106, 15,215-15,233.

A13. Doelling, D. R., P. Minnis, D. A. Spangenberg, V. Chakrapani, A. Mahesh, S. K. Pope, and F. P. J. Valero, 2001: Cloud radiative forcing during FIRE ACE derived from AVHRR data. J. Geophys. Res., 106, 15,279-15,296.

A14. Dong, X., G. G. Mace, P. Minnis, and D. F. Young, 2001: Arctic stratus cloud properties and their impact on the surface radiation budget; Selected cases from FIRE ACE. $J$. Geophys. Res., 106, 15,297-15,312.

A15. Pope, S. K., F. P. J. Valero, W. D. Collins, and P. Minnis, 2002: Comparison of SCARAB, GOES-8, aircraft, and surface observations of the absorption of solar radiation by clouds. J. Geophys. Res., 107 (D11), 10.1029/2001JD000672.

A16. Minnis, P., L. Nguyen, D. R. Doelling, D. F. Young, W. F. Miller, and D. P. Kratz, 2002: Rapid calibration of operational and research meteorological satellite imagers, Part I: Evaluation of research satellite visible channels as references. J. Atmos. Oceanic Technol., 19, 1233-1249.

A17. Minnis, P., L. Nguyen, D. R. Doelling, D. F. Young, W. F. Miller, and D. P. Kratz, 2002: Rapid calibration of operational and research meteorological satellite imagers, Part II: Comparison of infrared channels. J. Atmos. Oceanic Technol., 19, 1250-1266.

A18. Dong, X., P. Minnis, G. G. Mace, W. L. Smith, Jr., M. Poellot, R. T. Marchand, and A. D. Rapp, 2002: Comparison of stratus cloud properties deduced from surface, GOES, and aircraft data during the March 2000 ARM Cloud IOP. J. Atmos. Sci., 59, 3256-3284.

A19. Chepfer, H., P. Minnis, D. F. Young, L. Nguyen, and R. F. Arduini, 2002: Estimation of cirrus cloud effective ice crystal shapes using visible reflectances from dual-satellite measurements. J. Geophys. Res., 107 (D23), 10.1029/2000JD000240.

A20. Lin, B., P. Minnis, and A. Fan, 2003: Cloud liquid water amount variations with temperature observed during the SHEBA experiment. J. Geophys. Res., 108, 10.1029/2002JD002851.

A21. Sherwood, S. C., J.-H. Chae, P. Minnis, and M. McGill, 2004: Underestimation of deep convective cloud tops by thermal imagery. Geophys. Res. Lett., 31 (11), 10.1029/2004GL019699.

A22. Min, Q, P. Minnis, and M. M. Khaiyer, 2004: Comparison of cirrus optical depths from GOES-8 and surface measurements. J. Geophys. Res., 109, D20119, 10.1029/2003JD004390.

A23. Sherwood, S. C., P. Minnis, and M. McGill, 2004: Deep convective cloud top heights and their thermodynamic control during CRYSTAL-FACE. J. Geophys. Res., 109, No. D15, D15207, 10.1029/2004JD004811.

A24. Mace, G. G., Y. Zhang, S. Platnick, M. D. King, P. Minnis, and P. Yang, 2005:

Evaluation of cirrus cloud properties from MODIS radiances using cloud properties 
derived from ground-based data collected at the ARM SGP site. J. Appl. Meteorol., 44, 221-240.

A25. Huang, J., P. Minnis, B. Lin, Y. Yi, M. M. Khaiyer, R. F. Arduini, and G. G. Mace, 2005: Advanced retrievals of multilayered cloud properties using multi-sensor and multispectral measurements. J. Geophys. Res., 110, 10.1029/2004JD005101.

A26. Zhang, M. H., W. Y. Lin, S. A. Klein, J. T. Bacmeister, S. Bony, R. T. Cederwall, A. D. Del Genio, J. J. Hack, N. G. Loeb, U. Lohmann, P. Minnis, I. Musat, R. Pincus, P. Stier, M. J. Suarez, M. J. Webb, J. B. Wu, S. C. Xie, M.-S. Yao, and J. H. Zhang, 2005:

Comparing clouds and their seasonal variations in 10 atmospheric general circulation models with satellite measurements. J. Geophys. Res., 110, 10.1029/2004JD005021.

A27. Dong, X., P. Minnis, and B. Xi, 2005: A climatology of midlatitude continental clouds from the ARM SGP Central Facility: Part I: Low-level cloud macrophysical, microphysical and radiative properties. J. Climate, 18, 1008-1031.

A-28. Garrett, T. J., B. C. Navarro, D. G. Baumgardner, P. T. Bui, H. Gerber, R. L. Hermann, A. J. Heymsfield, E. J. Jensen, P. Lawson, P. Minnis, L. Nguyen, M. Poellot, S. K. Pope, F. P. J. Valero, C. H. Twohy, and E. M. Weinstock, 2005: In situ measurements of the microphysical and radiative evolution of a Florida cirrus anvil. J. Atmos. Sci. 62, 23522372.

A-29. Chepfer, H., V. Noel, P. Minnis, D. Baumgardner, L. Nguyen, G. Raga, M. J. McGill, and P. Yang, 2005: Particle habit in tropical ice clouds during CRYSTAL-FACE: Comparison of two remote sensing techniques with in situ observations. J. Geophys. Res., 110, D16204, 10.1029/2004JD005455.

A-30. Minnis, P., Y. Yi, J. Huang, and J. K. Ayers, 2005: Relationships between radiosonde and RUC-2 meteorological conditions and cloud occurrence determined from ARM data. $J$. Geophys. Res., 110, D23204, doi:10.1029/2005JD006005.

A-31. Sharon, T. M., B. A. Albrecht, H. H. Jonsson, P. Minnis, M. M. Khaiyer, T. M. Van Reken, J. Seinfeld, and R. Flagan, 2006: Aerosol and cloud microphysical characteristics of rifts and gradients in maritime stratocumulus clouds. J. Atmos. Sci., 63, 983-997.

A-32. Dong, X., B. Xi, P. Minnis, and C. N. Long, 2006: A climatology of midlatitude continental clouds from the ARM SGP Central Facility: Part II: Cloud fraction and radiative forcing. J. Climate, 19, 1765-1783.

A-33. Mace, G. G., S. Benson, K. L. Sonntag, S. Kato, Q. Min, P. Minnis, C. H. Twohy, M. Poellot, X. Dong, C. Long, Q. Zhang, and D. R. Doelling, 2006: Cloud radiative forcing at the ARM climate research facility: Part I. Technique, validation, and comparison to satellite-derived quantities. J. Geophys. Res., 111, 10.1029/2005JD005921.

A-34. Garrett, T. J., J. Dean-Day, C. Liu, B. K. Barnett, G. G. Mace, D. G. Baumgardner, C. R. Webster, T. P. Bui, W. G. Read, and P. Minnis, 2006: Convective formation of pileus near the tropopause. Atmos. Chem., \& Phys., 6, 1185-1200.

A-35. Kato, S., N. G. Loeb, P. Minnis, J. A. Francis, T. P. Charlock, D. Rutan, E. E. Clouthiaux, and S. Sun-Mack, 2006: Seasonal and interannual variations of top-ofatmosphere irradiance and cloud cover over polar regions derived from the CERES data set. Geophys. Res. Lett., 33, L19804, 10.1029/2006GL026685.

A-36. Huang, J., P. Minnis, B. Lin, Y. Yi, T.-F. Fan, S. Sun-Mack, and J. K. Ayers, 2006: Determination of ice water path in ice-over-water cloud systems using combined MODIS and AMSR-E measurements. Geophys. Res. Lett., 33, L21801, 10.1029/2006GL027038. 
A-37. Dong, X., B. Xi, and P. Minnis, 2006: Observational evidence of changes in water vapor, clouds, and radiation at the ARM SGP site. Geophys. Res. Lett., 33, L19818, 10.1029/2006GL027132.

A-38. Chiriaco, M., H. Chepfer, P. Minnis, M. Haeffelin, S. Platnick, D. Baumgardner, P. Dubuisson, M. McGill, V. Noel, J. Pelon, D. Spangenberg, S. Sun-Mack, and G. Wind, 2007: Comparison of CALIPSO-like, LaRC, and MODIS retrievals of ice cloud properties over SIRTA in France and Florida during CRYSTAL-FACE. J. Appl. Meteorol. Climatol., 46, 249-272.

A-39. Minnis, P., J. Huang, B. Lin, Y. Yi, R. F. Arduini, T.-F. Fan, J. K. Ayers, and G. G. Mace, 2007: Ice cloud properties in ice-over-water cloud systems using TRMM VIRS and TMI data. J. Geophys. Res., 112, 10.1029/2006JD007626.

A-40. Comstock, J. M., R. d'Entremont, D. DeSlover, G. G. Mace, S. Y. Matrosov, S. A. McFarlane, P. Minnis, D. Mitchell, K. Sassen, M. D. Shupe, D. D. Turner, and Z. Wang, 2007: An intercomparison of microphysical retrieval algorithms for upper tropospheric ice clouds. Bull. Am. Meteorol. Soc., 88, 191-204.

A41. Turner, D. D., A. M. Vogelmann, R. Austin, J. C. Barnerd, K. Cady-Pereira, C. Chiu, S. A. Clough, C. Flynn, M. M. Khaiyer, J. Liljegren, K. Johnson, B. Lin, C. Long, A. Marshak, S. Y. Matrosov, S. McFarlane, M. Miller, Q. Min, P. Minnis, W. O’Hirok, Z. Wang, and W. Wiscombe, 2007: Optically thin liquid water clouds: Their importance and our challenge. Bull. Am. Meteorol. Soc., 88, 177-190.

A42. Verlinde, H., J. Y. Harrington, G. M. McFarquhar, V. T. Yannuzzi, A. Avramov, S. Greenberg, N. Johnson, G. Zhang, M. R. Poellot, J. H. Mather, D. D. Turner, E. W. Eloranta, B. D. Zak, A. J. Prenni, J. S. Daniel, G. L. Kok, D. C. Tobin, R. Holz, K. Sassen, D. Spangenberg, P. Minnis, T. P. Tooman, M. D. Ivey, S. J. Richarson, C. P. Bahrmann, P. J. DeMott, A. J. Heymsfield, and R. Scholfield, 2007: The Mixed-Phase Arctic Cloud Experiment (M-PACE). Bull. Am. Meteorol. Soc., 88, 205-221.

A43. Wang, H., R. T. Pinker, P. Minnis, and M. M. Khaiyer, 2008: Experiments with cloud properties: Impact on surface radiative fluxes. J. Atmos. Oceanic Technol., 25, 10341040.

A44. Dong, X., P. Minnis, B. Xi, S. Sun-Mack, and Y. Chen, 2008: Comparison of CERESMODIS stratus cloud properties with ground-based measurements at the DOE ARM Southern Great Plains site. J. Geophys. Res., 113, D03204, doi:10.1029/2007JD008438.

A45. Dong, X., B. A. Wielicki, B. Xi, Y. Hu, G. G. Mace, S. Benson, F. Rose, S. Kato, T. Charlock, and P. Minnis, 2008: Using observations of deep convective systems to constrain atmospheric column absorption of solar radiation in the optically thick limit. $J$. Geophys. Res., 113, D10206, doi:10.1029/2007JD009769.

A46. Allen, G., G. Vaughan, D. Brunner, P. T. May, W. Heyes, P. Minnis, and J. K. Ayers, 2008: Modulation of tropical convection by breaking Rossby waves. Q. J. R. Meteorol. Soc.,doi:10.1002/qj.349.

A47. Minnis, P., 2002: Satellite Remote Sensing of Cirrus, Chapter 7 in Cirrus, Oxford University Press, D. K. Lynch, K. Sassen, D. O’C. Starr, and G. Stephens, Editors, pp. 147-167.

Conference and Meetings Papers and Presentations

C1. Minnis, P., M. M. Khaiyer, W. L. Smith, Jr., and L. Egli, 1999: Anisotropy in clear-sky infrared radiances over land from satellite and aircraft data. Second International 
Workshop on Multiangular Measurements and Models (IWMMM-2), Ispra, Italy, September 15-17.

C2. Minnis, P., D. R. Cahoon, S. Mayor, and D. R. Doelling, 1999: BRDFs derived from helicopter data over the ARM Southern Great Plains Site. Second International Workshop on Multiangular Measurements and Models (IWMMM-2), Ispra, Italy, September 15-17.

C3. Dong, X., G. G. Mace, P. Minnis, and D. F. Young, 1999: Arctic stratus cloud properties retrieved from ground-based measurements and validated by aircraft Data. Presented at 1999 Fall AGU Meeting, San Francisco, CA, December 13-17.

C4. Uttal, T., D. R. Doelling, P. Minnis, and B. W. Orr, 1999: Detection of cloud fraction over the Arctic ice pack: Comparison of AVHRR satellite data with ground-based cloud radar. Presented at 1999 Fall AGU Meeting, San Francisco, CA, December 13-17.

C5. Nordeen, M. L., D. R. Doelling, L. Nguyen, and P. Minnis, 2000: Cloud plumes observed at Nauru using GMS imagery. Proc. 10th ARM Science Team Mtg., San Antonio, TX, March 13-17, 2000.

C6. Duda, D. P. and P. Minnis, 2000: A study of skin temperature/cloud shadowing relationships at the ARM SGP site. Proc. 10th ARM Science Team Mtg., San Antonio, TX, March 13-17, 2000.

C7. Khaiyer, M. M., W. L. Smith, Jr. D. R. Doelling, and P. Minnis, 2000: Comparison of satellite-derived cloud and radiation properties with ship and surface observations during Nauru-99. 10th ARM Science Team Mtg., San Antonio, TX, March 13-17, 2000.

C8. Lin, B. and P. Minnis, 2000: Variations of land surface microwave emissivities over the ARM Southern Great Plains site. 10th ARM Science Team Mtg., San Antonio, TX, March 13-17, 2000.

C9. Smith, W. L., Jr., P. Minnis, P. W. Heck, D. F. Young, K. Kawamoto, and L. Nguyen, 2000: Improved satellite analyses for the ARM SGP. 10th ARM Science Team Mtg., San Antonio, TX, March 13-17, 2000.

C10. Chakrapani V., P. Minnis, D. R. Doelling, D. A. Spangenberg, R. F. Arduini, R. Palikonda, L. Nguyen, T. Uttal, and M. Shupe, 2000: AVHRR-derived cloud coverage over the ARM NSA and SHEBA Site during FIRE ACE. 10th ARM Science Team Mtg., San Antonio, TX, March 13-17, 2000.

C11. Minnis, P., D. R. Doelling, M. M. Khaiyer, and D. R. Cahoon, 2000: Surface reflectance anisotropy over the ARM SGP and the diurnal variation of surface spectral characteristics. 10th ARM Science Team Mtg., San Antonio, TX, March 13-17, 2000.

C12. Minnis, P., D. R. Doelling, V. Chakrapani, D. A. Spangenberg, A. Mahesh, S. K. Pope, and F. P. J. Valero, 2000: AVHRR-derived cloud radiative forcing over the ARM NSA and SHEBA site during FIRE ACE. 10th ARM Science Team Mtg, San Antonio, TX, March 13-17, 2000.

C13. Young D. F., P. Minnis, R. F. Arduini, and J. Woods-Vedeler, 2000: A comparison of satellite multispectral cloud microphysical retrievals over the ARM sites. 10th ARM Science Team Mtg., San Antonio, TX, March 13- 17, 2000.

C14. Dong, X., G. G. Mace, P. Minnis, and D. F. Young, 2000: Arctic stratus cloud properties and their effect on the surface radiation budget; selected cases from FIRE ACE. 10th ARM Science Team Mtg., San Antonio, TX, March 13-17, 2000.

C15. Dong. X., P. Minnis, G. G. Mace, S. Sun-Mack, E. E. Clothiaux, and C. N. Long, 2000: Validation of CERES/VIRS cloud property retrievals using ground-based measurements obtained at the DOE ARM sites. 10th ARM Science Team Mtg., San Antonio, TX, March 
$13-17,2000$.

C16. Dong, X., G. G. Mace, P. Minnis, and D. F. Young, 2000: Arctic stratus clouds and their effect on the surface radiation budget. FIRE/SHEBA Workshop, Boulder, CO, April 17-20.

C17. Minnis, P., D. F. Young, L. Nguyen, and D. Pethick, 2000: Cloud properties over the Arctic during SHEBA/FIRE ACE from ATSR-2 and AVHRR data. FIRE/SHEBA Workshop, Boulder, CO, April 17-20.

C18. Spangenberg, D. A., P. Minnis, V. Chakrapani, and D. R. Doelling, 2000: Cloud radiative forcing from AVHRR data over the Arctic during FIRE ACE. FIRE/SHEBA Workshop, Boulder, CO, April 17-20.

C19. Mahesh, A., D. A. Spangenberg, and P. Minnis, 2000: Night-time cloud detection in the Arctic from AVHRR data. FIRE/SHEBA Workshop, Boulder, CO, April 17-20.

C20. Minnis, P. and D. F. Young, 2000: Cloud microphysical properties derived from geostationary satellite data. Proc. EUMETSAT Meteorological Satellite Data Users Conf. 2000, Bologna, Italy, May 29-June 2, 299-305.

C21. Minnis, P., 2000: Validation of cloud properties using ARM time series. 2000 Gordon Research Conference on Solar Radiation and Climate. Connecticut College, New London, CT, June 24-29, 2000

C22. Minnis, P., L. Nguyen, D. F. Young, J. K. Ayers, D. R. Doelling, and V. Chakrapani, 2000: Intercalibration of operational and research meteorological satellites. 33rd COSPAR Scientific Assembly, Warsaw, Poland, July 16-23.

C23. Nguyen, L., J. K. Ayers, D. R. Doelling, P. Minnis, and D. F. Young, 2000: Rapid intercalibration of operational and research meteorological satellite imagers. IRS 2000 International Radiation Symposium, St. Petersburg, Russia, July 24-29.

C24. Smith, W. L., Jr., P. W. Heck, L. Nguyen, P. Minnis, D. F. Young, and K. Kawamoto, 2000: Cloud properties derived from geostationary satellite data from the Atmospheric Radiation Measurement (ARM) Program. IRS 2000 International Radiation Symposium, St. Petersburg, Russia, July 24-29.

C25. Heck, P. W., W. L. Smith, Jr., K. Kawamoto, P. Minnis, D. F. Young, S. Sun-Mack, R. F. Arduini, and X. Dong, 2000: An improved nighttime algorithm for operational cloud analysis. IRS 2000 International Radiation Symposium, St. Petersburg, Russia, July 24-29.

C26. Doelling, D. R., D. A. Spangenberg, V. Chakrapani, A. Mahesh, P. Minnis, T. Uttal, F. P. J. Valero, and S. K. Pope, 2000: Cloud radiative forcing over SHEBA and ARM NSA during FIRE-ACE from AVHRR. IRS 2000 International Radiation Symposium, St. Petersburg, Russia, July 24-29.

C27. Smith, W. L., Jr., P. Minnis, and D. F. Young, 2000: An icing product derived from operational satellite data. Proc. AMS 9th Conf. Aviation, Range, and Aerospace Meteorol., Orlando, FL, 11-15 Sept., 256-259.

C28. Lin, B., P. Minnis, A. Fan, and D. F. Young, 2001: Estimation of column water amounts over arctic regions using ground-based thermal microwave and infrared measurements. Proc. AMS 11th Symp on Meteorological Observations and Instrumentation, Albuquerque, NM, January 15-19, 168-170.

C29. Trepte, Q., R. F. Arduini, Y. Chen, S. Sun-Mack, P. Minnis, D. A. Spangenberg, and D. R. Doelling, 2001: Development of a daytime polar cloud mask using theoretical models of near- infrared bidirectional reflectance For ARM and CERES. Proc. AMS 6th Conf. on Polar Meteorology and Oceanography, San Diego, CA, May 14-18, 242-245.

C30. Spangenberg, D. A., V. Chakrapani, D. R. Doelling, P. Minnis, and R. F. Arduini, 2001: 
Evaluation of an automated Arctic cloud mask using observations from SHEBA and the ARM North Slope of Alaska Site. Proc. AMS 6th Conf. Polar Meteorology and Oceanography, San Diego, CA, May 14-18, 246-249.

C31. Minnis, P., W. L. Smith, Jr., and D. F. Young, 2001: Cloud macro- and microphysical properties derived from GOES over the ARM SGP domain. Proc. 11th ARM Science Team Meeting, March 18-22, Atlanta, GA. Available at http://www.arm.gov/docs/ documents/technical/conf_0103/author.html.

C32. Khaiyer, M. M., A. D. Rapp, P. Minnis, W. L. Smith, Jr., M. L. Nordeen, D. R. Doelling, and L. Nguyen, 2001: A three-year climatology of cloud and radiative properties derived from GOES-8 data over the southern Great Plains. Proc. 11th ARM Science Team Meeting, March 18-22, Atlanta, GA. Available at http://www.arm.gov/docs/documents/ technical/conf_0103/author.html.

C33. Kawamoto, K., P. Minnis, and W. L. Smith, Jr., 2001: Cloud overlapping detection algorithm using solar and ir wavelengths with GOES data over ARM/SGP site. Proc. 11th ARM Science Team Meeting, March 18-22, Atlanta, GA. Available at http://www.arm.gov/docs/documents/technical/conf_0103/author.html.

C34. Nordeen, M. L., D. R. Doelling, P. Minnis, M. M. Khaiyer, A. D. Rapp, and L. Nguyen, 2001. GMS-5 satellite- derived cloud properties over the tropical western Pacific. Proc. 11th ARM Science Team Meeting, March 18-22, Atlanta, GA. Available at http://www.arm.gov/docs/documents/technical/conf_0103/author.html.

C35. Rapp, A. D., D. R. Doelling, M. M. Khaiyer, P. Minnis, W. L. Smith, Jr., L. Nguyen, M. P. Haefflin, F. P. J. Valero, and S. Asano, 2001: Comparison of shortwave cloud radiative forcing derived from ARM SGP surface and GOES-8 satellite measurements during ARESE I and ARESE II. Proc. 11th ARM Science Team Meeting, March 18-22, Atlanta, GA. Available at http://www.arm.gov/docs/documents/technical/conf_0103/author.html.

C36. Chakrapani, V., D. A. Spangenberg, D. R. Doelling, P. Minnis, Q. Z. Trepte, and R. F. Arduini, 2001: Improvements in AVHRR daytime cloud detection over the ARM NSA Site. Proc. 11th ARM Science Team Meeting, March 18-22, Atlanta, GA. Available at http://www.arm.gov/docs/documents/technical/conf_0103/author.html.

C37. Dong, X., P. Minnis, M. Poellot, G. G. Mace, W. L. Smith, Jr., S. Sun-Mack, and R. Marchand, 2001. Comparison of boundary layer cloud properties deduced from surface, GOES/MODIS and aircraft data during March 2000 Cloud IOP. Presented at 11th ARM Science Team Meeting, March 18-22, Atlanta, GA.

C38. Nguyen, L., P. Minnis, J. K. Ayers, D. R. Doelling, W. L. Smith, Jr., and X. Dong, 2001: Intercalibration of Meteorological Satellite Imagers Using AVHRR, VIRS, ATSR-2, and MODIS. Presented at Spring AGU Meeting, May 29 -June 1, Boston, MA.

C39. Doelling, D. R., A. D. Rapp, M. M. Khaiyer, P. Minnis, W. L. Smith, Jr., L. Nguyen, M. P. Haeffelin, T. Tooman, F. P. J. Valero, and S. Asano, 2001: Cloud radiative forcing derived during ARESE-2. 8th Scientific Assembly of IAMAS, July 10-18, Innsbruck, Austria.

C40. Minnis, P., D. F. Young, W. L. Smith, Jr., X. Dong, G. G. Mace, and S. Sun-Mack, 2001: Validation of cloud properties derived from GOES, VIRS, and MODIS over ARM sites. Presented at 8th Scientific Assembly of IAMAS, July 10-18, Innsbruck, Austria.

C41. Lin, B. P. Minnis, A. Fan, D. A. Spangenberg, and T. Uttal, 2001: Diurnal variations in polar clouds observed from surface-based microwave radiometer. Presented at 8 th Scientific Assembly of IAMAS, July 10-18, Innsbruck, Austria.

C42. Rapp, A. D., D. R. Doelling, P. Minnis, and L. Nguyen, 2001: Comparison of TOA 
shortwave albedo and atmospheric solar absorption derived from GOES-8, CERES, aircraft, and surface measurements during ARESE- II with model calculations. Chapman Conference on Atmospheric Absorption of Solar Radiation. Estes Park, CO., August 13-17.

C43. Doelling, D. R., V. Chakrapani, P. Minnis, and L. Nguyen, 2001: The calibration of NOAA-AVHRR visible radiances with VIRS. Proc. AMS 11th Conf. Satellite Meteorology and Oceanography, Madison, WI, Oct. 15-18, 614-617.

C44. Minnis, P., W. L. Smith, Jr., D. F. Young, L. Nguyen, A. D. Rapp, P. W. Heck, S. SunMack, Q. Trepte, and Y. Chen, 2001: A near-real time method for deriving cloud and radiation properties from satellites for weather and climate studies. Proc. AMS 11th Conf. Satellite Meteorology and Oceanography, Madison, WI, Oct. 15-18, 477- 480.

C45. Nguyen, L., P. Minnis, J. K. Ayers, and D. R. Doelling, 2001: Intercalibration of meteorological satellite imagers using VIRS, ATSR-2, and MODIS. Proc. AMS 11th Conf. Satellite Meteorology and Oceanography, Madison, WI, Oct. 15-18, 442-445.

C46. Chen, Y., S. Sun-Mack, P. Minnis, D. F. Young, and W. L. Smith, Jr., 2001: Surface emissivity derived for infrared remote sensing from satellites. Proc. AMS 11th Conf. Satellite Meteorology and Oceanography, Madison, WI, Oct. 15-18, 512-515.

C46. Fan, A., B. Lin, P. Minnis, and D. A. Spangenberg, 2002: Cloud liquid water path variation with temperature during SHEBA/FIRE-ACE. Proc. AMS 6th Symp. Integrated Obs. Systems, Orlando, FL, Jan. 13-17, 218-219.

C47. Minnis, P., W. L. Smith, Jr., D. F. Young, and L. Nguyen, A. D. Rapp, P. W. Heck, and M. M. Khaiyer, 2002: Near-real time retrieval of cloud properties over the ARM CART area from GOES data. Proc. 12th ARM Science Team Meeting, St. Petersburg, FL, April 8-12.

C48. Nguyen, L., P. Minnis, D. F. Young, W. L. Smith, Jr., P. W. Heck, A. D. Rapp, and M. M. Khaiyer, 2002: Use of multi-resolution imager data to account for partially cloud-filled pixels. Proc. 12th ARM Science Team Meeting, St. Petersburg, FL, April 8-12.

C49. Heck, P. W., A. D. Rapp, P. Minnis, W. L. Smith, Jr., and L. Nguyen, 2002: An improved technique for retrieval of cloud properties at night and in low sun conditions. Proc. 12th ARM Science Team Meeting, St. Petersburg, FL, April 8-12.

C50. Nordeen, M. L., D. R. Doelling, M. M. Khaiyer, A. D. Rapp, and P. Minnis, 2002: A climatology of cloud and radiative properties derived from GMS-5 data over the tropical western Pacific. Proc. 12th ARM Science Team Meeting, St. Petersburg, FL, April 8-12.

C51. Chakrapani, V., D. R. Doelling, A. D. Rapp, and P. Minnis, 2002: Cloud thickness estimation from GOES-8 satellite data over the ARM SGP site. Proc. 12th ARM Science Team Meeting, St. Petersburg, FL, April 8-12.

C52. Khaiyer, M. M., P. Minnis, W. L. Smith, Jr., A. D. Rapp, D. R. Doelling, and L. Nguyen, 2002: Evaluation of a 5-year cloud and radiative property dataset derived from GOES-8 data over the southern Great Plains. Proc. 12th ARM Science Team Meeting, St. Petersburg, FL, April 8-12.

C53. Spangenberg, D. A., D. R. Doelling, P. Minnis, and T. Uttal, 2002: Nighttime cloud detection over the Arctic using AVHRR data. Proc. 12th ARM Science Team Meeting, St. Petersburg, FL, April 8-12.

C54. Dong, X., P. Minnis, S. Sun-Mack, and G. G. Mace, 2002: Validation of CERES/MODIS cloud property retrievals using ground-based measurements obtained at the DOE ARM SGP site. Proc. 12th ARM Science Team Meeting, St. Petersburg, FL, April 8-12.

C55. Smith, W. L., Jr., P. Minnis, B. C. Bernstein, A. D. Rapp, and P. W. Heck, 2002: Supercooled liquid water cloud properties derived from GOES: Comparisons with in-situ 
aircraft measurements. Proc. AMS 10th Conf. Aviation, Range, Aerospace Meteorol., Portland, OR, May 13-16.

C56. Doelling D. R., V. Chakrapani, P. Minnis, and L. Nguyen, 2002: The Intercalibration of visible NOAA AVHRR radiances with VIRS. AGU 2002 Spring Meeting, Washington D. C., May 28-31.

C57. Nguyen L., D. R. Doelling, P. Minnis, J. K. Ayers, 2002: Cross calibration of GOES, Meteosat-7, GMS-5, and NOAA-14 AVHRR visible sensors. AGU 2002 Spring Meeting, Washington D. C., May 28-31.

C58. Arduini, R. F., P. Minnis, and D. F. Young, 2002: Investigation of a visible reflectance parameterization for determining cloud properties in multi-layered clouds. Proc. AMS 11th Conf. Cloud Physics, Ogden, UT, June 3-7.

C59. Spangenberg, D. A., P. W. Heck, P. Minnis, Q. Trepte, S. Sun-Mack, T. Uttal, S. Matrosov, and X. Dong, 2002: Arctic cloud properties derived from multispectral MODIS and AVHRR data. Proc. AMS 11th Conf. Cloud Physics, Ogden, UT, June 3-7.

C60. Kawamoto, K., P. Minnis, W. L. Smith, Jr., and A. D. Rapp, 2002: Detecting multilayer clouds using satellite solar and IR channels. Proc. AMS 11th Conf. Cloud Physics, Ogden, UT, June 3-7.

C61. Rapp, A. D., D. R. Doelling, M. M. Khaiyer, P. Minnis, W. L. Smith, Jr., and L. Nguyen, 2002: Analysis of solar absorption derived from ARM surface and satellite measurements. Proc. $11^{\text {th }}$ AMS Conf. Atmos. Rad., Ogden, UT, June 3-7, 43-46.

C62. Ayers, J. K., P. Minnis, R. Wood, P. W. Heck, D. F. Young, W. L. Smith, Jr., C. W. Fairall, and T. Uttal, 2002: Validation of GOES-8 derived cloud properties over the southeastern Pacific. AGU 2002 Fall Meeting, San Francisco, CA, December 6-10.

C63. Chakrapani, V., D. R. Doelling, M. M. Khaiyer, and P. Minnis, 2003: New visible to broadband shortwave conversions for deriving albedos from GOES-8 over the ARM SGP. Proc. 13th ARM Science Team Meeting, Broomfield, CO, March 31 - April 4. (Available at http://www.arm.gov/docs/documents/technical/conf_0304/chakrapani-v.pdf)

C64. Doelling, D. R., M. L. Nordeen, M. M. Khaiyer, and P. Minnis, 2003: Improved ARMSGP OLR fluxes from GOES-8 based on CERES. Proc. 13th ARM Science Team Meeting, Broomfield, CO, March 31 - April 4. (Available at http://www.arm.gov/docs/documents/technical/conf_0304/doelling-dr.pdf)

C65. Minnis, P., D. A. Spangenberg, and V. Chakrapani, 2003: Distribution and validation of cloud cover derived from AVHRR data over the Arctic Ocean during the SHEBA year. Proc. 13th ARM Science Team Meeting, Broomfield, CO, March 31 - April 4. (Available at http://www.arm.gov/docs/documents/technical/conf_0304/minnis-p.pdf)

C66. Nowicki, G. D., M. L. Nordeen, P. W. Heck, D. R. Doelling, M. M. Khaiyer, P. Minnis, and, S. Sun-Mack, 2003: Cloud microphysical and radiative properties derived from MODIS, VIRS, AVHRR, and GMS data over the Tropical Western Pacific. Proc. 13th ARM Science Team Meeting, Broomfield, CO, March 31 - April 4 (Available at http://www.arm.gov/docs/documents/technical/conf_0304/nowicki-gd.pdf).

C67. Genkova, I., C. N. Long, P. W. Heck, and P. Minnis, 2003: Satellite and surface data synergy for developing a 3- D cloud structure and properties characterization over the ARM SGP. 13th ARM Science Team Meeting, Broomfield, CO, March 31 - April 4. (Available at http://www.arm.gov/docs/documents/technical/conf_0304/genkova-i.pdf)

C68. Khaiyer, M. M., P. Minnis, B. Lin, W. L. Smith, Jr., and A. D. Rapp, 2003: Validation of satellite-derived liquid water paths using ARM SGP microwave radiometers. Proc. 13th 
ARM Science Team Meeting, Broomfield, CO, March 31 - April 4. (Available at http://www.arm.gov/docs/documents/technical/conf_0304/khaiyer-mm.pdf)

C69. Huang, J. P., M. M. Khaiyer, P. W. Heck, P. Minnis, and B. Lin, 2003: Determination of ice-water path over the ARM SGP using combined surface and satellite datasets. Proc. 13th ARM Science Team Meeting, Broomfield, CO, March 31 - April 4. (Available at http://www.arm.gov/docs/documents/technical/conf_0304/huang-j.pdf)

C70. Heck, P. W., M. M. Khaiyer, P. Minnis, W. L. Smith, Jr., D. F. Young, and L. Nguyen, 2003: Evaluation of day- night continuity in retrievals of cloud properties from GOES. 13th ARM Science Team Meeting, Broomfield, CO, March 31 - April 4.

C71. Doelling, D. R., P. Minnis, M. M. Khaiyer, L. Nguyen, and W. L. Smith, Jr., 2003: Cirrus cloud life cycles during CRYSTAL-FACE from GOES data. 2003 EGS-AGU-EUG Joint Assembly, Nice, France, April 7-11.

C72. Nguyen, L., P. Minnis, D. R. Doelling, W. L. Smith, Jr., D. P. Duda, M. Khaiyer, M. Poellot, G. G. Mace, and T. Uttal, 2003: Comparison of surface, satellite, and aircraft ice cloud properties during CRYSTAL-FACE. 2003 EGS-AGU-EUG Joint Assembly, Nice, France, April 7-11.

C73. Spangenberg, D. A., V. Chakrapani, and P. Minnis, 2003: Cloud climatology of the SHEBA year derived from an automated Arctic cloud mask. Proc. 7th AMS Conf. Polar Meteorology and Oceanography, Hyannis, MA, 7-10 May, CD-ROM, 7.6.

C74. Uttal, T., S. Sun-Mack, P. Minnis, and J. Key, 2003: Comparison of surface and satellite measurements of Arctic cloud properties. Proc. 7th AMS Conf. Polar Meteorology and Oceanography, Hyannis, MA, 7-10 May, CD-ROM, 7.3.

C75. Lin, B., P. Minnis, and A. Fan, 2003: The change of cloud liquid water path on temperature over polar areas. Proc. 7th AMS Conf. Polar Meteorology and Oceanography, Hyannis, MA, 7-10 May, CD-ROM, 5.14.

C76. Minnis, P., W. L. Smith, Jr., L. Nguyen, J. J. Murray, P. W. Heck, and M. M. Khaiyer, 2003: Near-real-time satellite cloud products for icing detection and aviation weather over the USA. Proc. FAA In-Flight Icing/De-icing International Conference, Chicago, IL, June 16-20, CD_ROM, 2003-01-2097.

C77. Smith, W. L., Jr., P. Minnis, B. C. Bernstein, F. McDonough, and M. M. Khaiyer, 2003: Comparison of supercooled liquid water cloud properties derived from satellite and aircraft measurements. Proc. FAA In-Flight Icing/De-icing International Conference, Chicago, IL, June 16-20, CD_ROM, 2003-01-2156.

C78. Chen, Y., S. Sun-Mack, P. Minnis, D.F. Young, and W. L. Smith, Jr., 2003: Surface spectral emissivity derived from Aqua MODIS data. IUGG 2003 Cloud, Aerosols, Radiation, and Climate Symposium, Sapporo, Japan, June 30 - July 11.

C79. Ayers, J. K., M. M. Khaiyer, P. Minnis, L. Nguyen, T. Sharon, B. A. Albrecht, C. W. Fairall, T. Uttal, and R. Wood, 2003: Comparison of in situ, surface, and satellite cloud measurements over the eastern Pacific. U.S. CLIVAR PanAmerican Workshop, Boulder, CO, September 15-18.

C80. Nguyen, L., P. Minnis, D. F. Young, W. L. Smith, Jr., P. W. Heck, A. D. Rapp, and S. Sun-Mack, 2002: Accounting for partially cloud-filled pixels using multi-resolution imager data. Proc. $11^{\text {th }}$ AMS Conf. Atmos. Rad., Ogden, UT, June 3-7, J31-J34.

C81. Trepte, Q. Z., P. Minnis, and D. A. Spangenberg, 2003: Improved nighttime and twilight polar cloud detection algorithms using Terra and Aqua observations. 2003 AGU Fall Meeting, San Francisco, CA, December 8-12. 
C82. Navarro, B. C., T. J. Garrett, D. Baumgardner, P. Bui, H. Gerber, A. Heymsfield, P. Lawson, P. Minnis, M. Poellot, C. Twohy, W. Weinstock, and R. Herman, 2003: The microphysical and radiative evolution of a cirrus anvil during CRYSTAL-FACE. 2003 AGU Fall Meeting, San Francisco, CA, December 8-12.

C83. Yi, Y.-H., P. Minnis, J. K. Ayers, J.-P. Huang, 2004: Relationships between meteorological conditions and cloud properties determined from ARM data. Proc. 14th ARM Science Team Meeting, Albuquerque, NM, March 22-26. (Available at http://www.arm.gov/publications/proceedings/conf14/extended_abs/yi-yh.pdf)

C84. Spangenberg, D. A., P. Minnis, T. Uttal, Q. Trepte, and S. Sun-Mack, 2004: Derivation of seasonal cloud properties at ARM-NSA from multispectral MODIS data. Proc. 14th ARM Science Team Meeting, Albuquerque, NM, March 22-26. (Available at http://www.arm.gov/publications/proceedings/conf14/extended_abs/spangenberg-da.pdf)

C85. Huang, J.-P., P. Minnis, B. Lin, Y.-H. Yi, R. F. Arduini, and G. G. Mace, 2004: Advanced retrievals of multilayered cloud properties using multi-sensor and multi-spectral measurements. Proc. 14th ARM Science Team Meeting, Albuquerque, NM, March 22-26. (Available at http://www.arm.gov/publications/proceedings/conf14/extended_abs/huangjp.pdf)

C86. Khaiyer, M. M., M. L. Nordeen, P. Minnis, W. L. Smith, Jr., D. R. Doelling, and V. Chakrapani, 2004: Validation of cloud properties derived from GOES-9 over the ARM TWP region. Proc. 14th ARM Science Team Meeting, Albuquerque, NM, March 22-26. (Available at http://www.arm.gov/publications/proceedings/conf14/extended_abs/khaiyermm.pdf)

C87. Minnis, P., D. P. Kratz, T. P. Charlock, D. R. Doelling, M. L. Nordeen, M. M. Khaiyer, S. K. Gupta, and D. Rutan, 2004: Surface radiation budget from ARM satellite retrievals. Proc. 14th ARM Science Team Meeting, Albuquerque, NM, March 22-26. (Available at http://www.arm.gov/publications/proceedings/conf14/extended_abs/minnis-p.pdf)

C88. Minnis, P., L. Nguyen, D. F. Young, and W. L. Smith, Jr., 2004: Near-real time cloud and radiation products from GOES-R ABI. 3rd GOES-R User Conference, Boulder, CO, May 10-13.

C89. Doelling, D. R., L. Nguyen, and P. Minnis, 2004: Calibration comparisons between SEVIRI, MODIS, and GOES data. Proc. 2004 EUMETSAT Meteorological Satellite Conf., Prague, Czech Rep., 17 - 20 May.

C90. Minnis, P., L. Nguyen, D. F. Young, R. Palikonda, G. D. Nowicki, P. W. Heck, and M. Haeffelin, 2004: Near-real time cloud products from MSG data. 2004 EUMETSAT Meteorological Satellite Conf., Prague, Czech Rep., 17 - 20 May.

C91. Minnis, P., R. F. Arduini, D. F. Young, J. K. Ayers, B. A. Albrecht, T. Sharon, and B. Stevens, 2004: An examination of the impact of drizzle drops on satellite-retrieved effective particle sizes. Proc. 14th Intl. Conf. Clouds and Precipitation, Bologna, Italy, 18-23 July, 600-603.

C92. Albrecht, B. A., T. Sharon, H. Jonsson, P. Minnis, J. K. Ayers, and M. M. Khaiyer, 2004: Evidence for natural variability in marine stratocumulus cloud properties due to cloudaerosol interactions. Proc. 14th Intl. Conf. Clouds and Precipitation, Bologna, Italy, 18-23 July, 5-8.

C93. Dong, X., B. Xi, P. Minnis, B. Wielicki, S. Sun-Mack, Y. Chen, and G. G. Mace, 2004: Validation of CERES ST-derived MODIS cloud properties using ground-based measurements at the DOE ARM SGP. Presented at IRS 2004, Busan, South Korea, August 
23-28.

C94. Minnis, P., W. L. Smith, Jr., L. Nguyen, D. A. Spangenberg, P. W. Heck, R. Palikonda, J. K. Ayers, C. Wolff, and J. J. Murray, 2004: Near-real time cloud properties and aircraft icing indices from GEO and LEO satellites. Proc. SPIE 49th Ann. Mtg., Earth Observing Systems IX Conf., Denver, CO, August 2-6. (Invited)

C95. Doelling, D. R., L. Nguyen, and P. Minnis, 2004: On the use of deep convective clouds to calibrate AVHRR data. Proc. SPIE 49th Ann. Mtg., Earth Observing Systems IX Conf., Denver, CO, August 2-6.

C96. Nguyen, L., D. R. Doelling, P. Minnis, and J. K. Ayers, 2004: Rapid technique to cross calibrate satellite imager visible channels. Proc. SPIE 49th Ann. Mtg., Earth Observing Systems IX Conf., Denver, CO, August 2-6.

C97. Minnis, P., L. Nguyen, D. F. Young, D. R. Doelling, M. L. Nordeen, D. A. Spangenberg, R. Palikonda, G. D. Nowicki, and M. Haeffelin, 2004: Comparison of cloud properties from Meteosat-8 and surface observations. Proc. MSG RAO Workshop, Salzburg, Austria, 10-11 September.

C98. Doelling, D. R., P. Minnis, and L. Nguyen, 2004: Calibration comparisons between SEVIRI, MODIS, and GOES data. Proc. MSG RAO Workshop, Salzburg, Austria, 10-11 September.

C99. Chen, Y., S. Sun-Mack, P. Minnis, D. F. Young, and W. L. Smith, Jr., 2004: Seasonal surface spectral emissivity derived from Terra MODIS data. Proc. 13th AMS Conf. Satellite Oceanogr. and Meteorol., Norfolk, VA, Sept. 20-24, CD-ROM, P2.4.

C100. Spangenberg, D. A., Q. Trepte, P. Minnis, and T. Uttal, 2004: Daytime cloud property retrievals over the Arctic from multispectral MODIS data. Proc. 13th AMS Conf. Satellite Oceanogr. and Meteorol., Norfolk, VA, Sept. 20-24, CD-ROM, P7.11.

C101. Khaiyer, M. M., M. L. Nordeen, D. R. Doelling, V. Chakrapani, P. Minnis, and W. L. Smith, Jr., 2004: Validation of GOES-9 satellite-derived cloud properties over the tropical western Pacific region. Proc. 13th AMS Conf. Satellite Oceanogr. and Meteorol., Norfolk, VA, Sept. 20-24, CD-ROM, P7.6.

C102. Yi, Y., P. Minnis, J. Huang, and J. K. Ayers, 2004: Cloud detection using measured and modeled state parameters. Proc. 13th AMS Conf. Satellite Oceanogr. and Meteorol., Norfolk, VA, Sept. 20-24, CD-ROM, P6.11.

C103. Gambheer, A. V., D. R. Doelling, D. A. Spangenberg, and P. Minnis, 2004: Validation of infrared azimuthal model as applied to GOES data over the ARM SGP. Proc. 13th AMS Conf. Satellite Oceanogr. and Meteorol., Norfolk, VA, Sept. 20-24, CD-ROM, P8.6.

C104. Huang, J., P. Minnis, B. Lin, Y. Yi, J. K. Ayers, R. Arduini, and T.-F. Fan, 2004: Development of a multilayered cloud retrieval system. Proc. 13th AMS Conf. Satellite Oceanogr. and Meteorol., Norfolk, VA, Sept. 20-24, CD- ROM, P7.20.

C105.Minnis, P., L. Nguyen, W. L. Smith, Jr., M. M. Khaiyer, R. Palikonda, D. A. Spangenberg, D. R. Doelling, D. Phan, G. D. Nowicki, P. W. Heck, and C. Wolff, 2004: Real-time cloud, radiation, and aircraft icing parameters from GOES over the USA. Proc. 13th AMS Conf. Satellite Oceanogr. and Meteorol., Norfolk, VA, Sept. 20-24, CD-ROM, P7.1.

C106. Phan, D., D. A. Spangenberg, R. Palikonda, M. M. Khaiyer, M. L. Nordeen, L. Nguyen, and P. Minnis, 2004: Web-based satellite products database for meteorological and climate applications. Proc. 13th AMS Conf. Satellite Oceanogr. and Meteorol., Norfolk, VA, Sept. 20-24, CD-ROM, P8.2.

C107. Minnis, P., L. Nguyen, R. Palikonda, D. Spangenberg, M. L. Nordeen, Y. Yi, and J. K. 
Ayers, 2004: Toward a three-dimensional near-real time cloud product for aviation safety and weather diagnoses. Proc. AMS 11th Conf Aviation, Range, and Aerospace. Hyannis, MA, October4-8, CD-ROM, 8.11.

C108. Nguyen, L., P. Minnis, D. A. Spangenberg, M. L. Nordeen, R. Palikonda, M. M. Khaiyer, and I. Gultepe, 2004: Comparison of satellite and aircraft measurements of cloud microphysical properties in icing conditions during ATREC/AIRS-II. Proc. AMS 11th Conf Aviation, Range, and Aerospace. Hyannis, MA, October 4-8, CD-ROM, P6.10.

C109. Genkova, I., C. Long, P. Heck, P. Minnis, and M. Khaiyer, 2004: Point-to-point comparison of satellite and ground-based cloud properties at the ARM Southern Great Plains Central Facility. Proc. SPIE 4th Intl. Asia-Pac. Environ. Rem. Sens. Symp. 2004 Passive Opt. Rem. Sens. Atmos. and Clouds IV Conf., Honolulu, HI, November 8-12.

C110. Uttal, T., S. Frisch, X. Wang, J. Key, A. Schweiger, S. Sun-Mack, and P. Minnis, 2005: Comparison of monthly mean cloud fraction and cloud optical depth determined from surface cloud radar, TOVS, AVHRR, and MODIS over Barrow, Alaska. Proc. AMS 8th Conf. Polar Meteorol., San Diego, CA, January 9-13, CD-ROM, P1.27.

C111. Mace, G., S. Benson, K. Sonntag, S. Kato, Q. Min, P. Minnis, C. Twohy, M. Poellot, X. Dong, Q. Zhang, and C. Long, 2005: Cloud radiative forcing at the ARM climate research facility: Part 1. Technique, validation, and comparison to satellite-derived diagnostic quantities. 15th ARM Sci. Team Mtg., Daytona Beach, FL, March 14- 18.

C112. Genkova, I., C. Long, P. Minnis, P. W. Heck, and M. Khaiyer, 2005: Clouds over the ARM SGP network area - 3D perspective. 15th ARM Sci. Team Mtg., Daytona Beach, FL, March 14-18.

C113. Khaiyer, M., R. Arduini, P. Minnis, J. Huang, R. Palikonda, G. Nowicki, and B. Lin, 2005: Comparisons of cloud liquid water paths over the ARM SGP using satellite and surface data: validation of new models. Proc. 15th ARM Sci. Team Mtg., Daytona Beach, FL, March 14-18.

C114. Minnis, P., M. Khaiyer, Y. Yi, S. Sun-Mack, R. Palikonda, D. Spangenberg, and J. Huang, 2005: Developing a 3-D cloud product over the ARM sites using GOES data. Proc. 15th ARM Sci. Team Mtg., Daytona Beach, FL, March 14-18.

C115. Ayers, J. K., P. Minnis, R. Palikonda, P. Heck, and R. F. Arduini, 2005: Evaluation of cloud properties derived from dual-view satellite data over the continental United States. Proc. 15th ARM Sci. Team Mtg., Daytona Beach, FL, March 14-18.

C116. Trepte, Q.Z., P. Minnis, and R. Palikonda, 2005: Improvements in near-terminator and nocturnal cloud masks using satellite imager data over the ARM sites. Proc. 15th ARM Sci. Team Mtg., Daytona Beach, FL, March 14- 18.

C117. Turner, D., A. Vogelmann, S. Clough, J. Liljegren, A. Marshak, M. Miller, Q. Min, C. Flynn, P. Heck, B. Lin, C. Long, S. McFarlane, P. Minnis, Z. Wang, and J.-Y. Chiu, 2005: Microphysical properties of clouds with low liquid water paths: An update from CLOWD. Proc. 15th ARM Sci. Team Mtg., Daytona Beach, FL, March 14-18.

C118. Albrecht, B. A., P. Kallos, I. Jo, V. Ghate, E. Serpetzoglou, P. Minnis, S. Sun-Mack, 2005: Observations of natural variability in marine stratocumulus clouds. Proc. 15th ARM Sci. Team Mtg., Daytona Beach, FL, March 14-18.

C119. Spangenberg, D. A., Q. Trepte, S. Sun-Mack, P. Minnis, M. Shupe, and T. Uttal, 2005: Retrieval of cloud properties using MODIS and AVHRR data during MPACE. Proc. 15th ARM Sci. Team Mtg., Daytona Beach, FL, March 14-18.

C120. Arduini, R. F., P. Minnis, and J. K. Ayers, 2005: Sensitivity of satellite-derived cloud 
properties to the spectral dispersion of cloud droplet distribution. Proc. 15th ARM Sci. Team Mtg., Daytona Beach, FL, March 14-18.

C121. Doelling, D. R., D. Phan, D. A. Spangenberg, and P. Minnis, 2005: Validation of retrieved cloud amounts over the continental US with ASOS ceilometer data. Proc. 15th ARM Sci. Team Mtg., Daytona Beach, FL, March 14- 18.

C122. Palikonda, R., P. Minnis, M. Khaiyer, P. Heck, D. Doelling, L. Nguyen, J. Ayers, D. Spangenberg, M. Nordeen, R. Arduini, Q. Trepte, S. Sun-Mack, and G. Nowicki, 2005: Overview of ARM satellite cloud and radiation products from NASA LaRC. Proc. 15th ARM Sci. Team Mtg., Daytona Beach, FL, March 14-18.

C123. Dong, X., B. Xi, and P. Minnis, 2005: A climatology of midlatitude continental clouds from the ARM SGP Central Facility: Part II: Cloud fraction and radiative forcing. 15th ARM Sci. Team Mtg., Daytona Beach, FL, March 14-18.

C124. Dong, X., B. Xi, and P. Minnis, 2005: A climatology of midlatitude continental clouds from the ARM SGP Central Facility: Part III: Comparison of low cloud properties between GOES and surface. 15th ARM Sci. Team Mtg., Daytona Beach, FL, March 14-18.

C125. Nordeen, M. L., P. Minnis, M. M. Khaiyer, D. R. Doelling, and D. N. Phan, 2005: Comparison of surface and satellite-derived cloud and radiation properties at the ARM SGP and TWP sites. 15th ARM Sci. Team Mtg., Daytona Beach, FL, March 14-18.

C126. Minnis, P., L. Nguyen, S. Sun-Mack, Y. Chen, M. Khaiyer, R. Palikonda, 2005: Development of three-dimensional cloud fields using multiple data sources. 3rd PanGCSS Meeting on Clouds, Climate and Models, Athens, Greece, May 16-20, 2005.

C127. Xi, B., X. Dong, and P. Minnis, 2005: A climatology of midlatitude continental clouds from the ARM SGP Central Facility: cloud fraction and radiative forcing. Geolog. Soc. America Earth Syst. Processes Conf., Calgary, Canada, August 8-11.

C128. Minnis, P., L. Nguyen, W. L. Smith, Jr., J. J. Murray, R. Palikonda, M. M. Khaiyer, D. A. Spangenberg, P. W. Heck, and Q. Z. Trepte, 2005: Near real-time satellite cloud products for nowcasting applications. Proc. WWRP Symp. Nowcasting \& Very Short Range Forecasting, Toulouse, France, 5-9 September, CD-ROM 4.19.

C129. Ayers, J. K., R. Palikonda, M. Khaiyer, D. R. Doelling, M. Nordeen, D. Spangenberg, D. Phan, P. Chan, P. Minnis, L. Nguyen, P. Heck, Q. Trepte, S. Sun-Mack, R. Arduini, and X. Dong, 2005: Update of NASA Langley cloud products for model evaluation and assimilation. Presented at ARM Cloud Parameterization and Modeling Working Group Annual Meeting, Stony Brook, NY, October 12-13.

C130. Chan, P., M. L. Nordeen, D. R. Doelling, J. K. Ayers, R. Palikonda, M. M. Khaiyer, and P. Minnis, 2005: Validation of satellite-retrieved surface radiative fluxes with SURFRAD measurements over the United States. Presented at ARM Instantaneous Radiative Flux Working Group Mtg., Annapolis, MD, November 2-4.

C131. M. Khaiyer, R. Palikonda, J. K. Ayers, D. R. Doelling, M. Nordeen, D. Spangenberg, D. Phan, P. Chan, Y. Yi, J. Huang, P. K. Chan, P. Minnis, L. Nguyen, P. Heck, Q. Trepte, S. Sun-Mack, and R. Arduini, 2005: Overview and validation of NASA Langley satellitederived cloud and radiation products. Presented at ARM Cloud Properties Working Group Mtg., Annapolis, MD, November 2-4.

C132. Spangenberg, D. A., P. Minnis, M. D. Shupe, M. R. Poellot, and Z. Wang, 2005: Detection of mixed-phase clouds over the ARM-NSA site using MODIS 6.7-12 micron data. Presented at ARM Cloud Properties Working Group Mtg., Annapolis, MD, November 2-4. 
C133. Spangenberg, D. A., P. Minnis, M. D. Shupe, M. R. Poellot, and Z. Wang, 2005: Detection of mixed-phase clouds over the Arctic using MODIS 6.7-12 micron data. 2005 AGU Fall Meeting, San Francisco, CA, December 5-9.

C134. Ayers, J. K., R. Palikonda, M. M. Khaiyer, P. Minnis, L. Nguyen, W. L. Smith, Jr., and R. Arduini, 2006: Angular dependence of cloud property retrievals from satellite data. Proc. AMS 14th Conf. Satellite Meteorol. and Oceanog., Atlanta, GA, 29 Jan. - 2 Feb., CDROM, 1.4.

C135. Khaiyer, M. M., R. Palikonda, M. L. Nordeen, J. K. Ayers, P. Minnis, and R. F. Arduini, 2006: Validation of satellite-derived liquid water paths with ground-based microwave radiometers for various cloud regimes. Proc. AMS 14th Conf. Satellite Meteorol. and Oceanog., Atlanta, GA, 29 Jan. - 2 Feb., CD-ROM, P5.3.

C136. Nordeen, M. L., D. R. Doelling, P. K. Chan, M. M. Khaiyer, D. Phan, J. K. Ayers, R. Palikonda, and P. Minnis, 2006: Satellite-derived surface radiation fluxes at the ARM SGP and TWP Manus CART sites. Proc. AMS 14th Conf. Satellite Meteorol. and Oceanog., Atlanta, GA, 29 Jan. - 2 Feb., CD-ROM, P2.7.

C137. Palikonda, R., D. Phan, M. M. Khaiyer, M. L. Nordeen, J. K. Ayers, D. A. Spangenberg, D. R. Doelling, Y. Yi, P. Minnis, L. Nguyen, Q. Trepte, and S. Sun-Mack, 2006: NASALangley web-based operational real-time cloud retrieval products from geostationary satellites. Proc. AMS 14th Conf. Satellite Meteorol. and Oceanog., Atlanta, GA, 29 Jan. 2 Feb., CD-ROM, P4.18.

C138. Minnis, P., L. Nguyen, R. Palikonda, P. W. Heck, D. A. Spangenberg, D. R. Doelling, J. K. Ayers, W. L. Smith, Jr., M. M. Khaiyer, Q. Z. Trepte, L. A. Avey, F.-L. Chang, C. R. Yost, T. L. Chee, and S. Sun-Mack, 2008: Near-real time cloud retrievals from operational and research meteorological satellites. Proc. SPIE Europe Remote Sens. 2008, Cardiff, Wales, UK, 15-18 September, 7107-2, 8 pp. 